\title{
Triptolide induces lysosomal-mediated programmed cell death in MCF-7 breast cancer cells
}

This article was published in the following Dove Press journal:

International Journal of Women's Health

4 September 2013

Number of times this article has been viewed

\author{
Chie Owa \\ Michael E Messina Jr \\ Reginald Halaby \\ Department of Biology, Montclair \\ State University, Montclair, NJ, USA
}

Correspondence: Reginald Halaby Department of Biology and Molecular Biology, Montclair State University, I Normal Avenue, Montclair, NJ 07043, USA

$\mathrm{Tel}+$ I 9736557982

Fax + I 9736557047

Email halabyr@montclair.edu
Background: Breast cancer is a major cause of death; in fact, it is the most common type, in order of the number of global deaths, of cancer in women worldwide. This research seeks to investigate how triptolide, an extract from the Chinese herb Tripterygium wilfordii Hook F, induces apoptosis in MCF-7 human breast cancer cells. Accumulating evidence suggests a role for lysosomal proteases in the activation of apoptosis. However, there is also some controversy regarding the direct participation of lysosomal proteases in activation of key apoptosis-related caspases and release of mitochondrial cytochrome c. In the present study, we demonstrate that triptolide induces an atypical, lysosomal-mediated apoptotic cell death in MCF-7 cells because they lack caspase-3.

Methods: MCF-7 cell death was characterized via cellular morphology, chromatin condensation, 3-(4,5-dimethylthiazol-2-yl)-2,5-diphenyltetrazolium bromide colorimetric cell growth inhibition assay and the expression levels of proapoptotic proteins. Acridine orange and LysoTracker ${ }^{\circledR}$ staining were performed to visualize lysosomes. Lysosomal enzymatic activity was monitored using an acid phosphatase assay and western blotting of cathepsin B protein levels in the cytosolic fraction, which showed increased enzymatic activity in drug-treated cells.

Results: These experiments suggest that triptolide-treated MCF-7 cells undergo atypical apoptosis and that, during the early stages, lysosomal enzymes leak into the cytosol, indicating lysosomal membrane permeability.

Conclusion: Our results suggest that further studies are warranted to investigate triptolide's potential as an anticancer therapeutic agent.

Keywords: triptolide, MCF-7 breast cancer cells, apoptosis, lysosomes, lysosomal membrane permeabilization (LMP)

\section{Introduction}

Breast cancer is the second deadliest cancer among women in the United States, and the National Cancer Institute now estimates that one in seven women living in the United States will develop breast cancer in their lifetime. ${ }^{1}$ With rates of breast cancer increasing, it will continue to be a major cause of cancer deaths in women worldwide..$^{2,3}$ Treatments such as chemotherapy and radiation are known to have harmful side effects on normal cells. Therefore, it is imperative to develop safer and noninvasive treatments. The use of natural products in the fight against cancer is one possible way of slowing tumor growth and may allow us to design more effective therapies.

Triptolide is an extract from the Chinese herb Tripterygium wilfordii Hook F. Long used in traditional Chinese medicine, the herb is purported to have immunosuppressive and anti-inflammatory properties, ${ }^{4,5}$ and triptolide has been identified as a major 
chemical component governing these properties. Triptolide is a diterpenoid triepoxide. Looking at the chemical composition of triptolide, it is a derivative of isoprene, which is part of the terpene family. Triptolide consists of four isoprene molecules. ${ }^{6}$ Through the biosynthetic processing of the isoprene units in some plants, certain precursors to vitamins A and $\mathrm{E}$ are produced. ${ }^{6,7}$ These strong antioxidants may account for some of triptolide's anticancer effects. A recent report demonstrated that triptolide covalently binds to a subunit of the general transcription factor TFIIH, and therefore inhibits RNA polymerase II-mediated transcription. ${ }^{8}$ So far, the mechanisms proposed for the potent anticancer activity of triptolide, at concentrations in the $\mathrm{nM}$ range, include caspase activation in U937 human promonocytic cells, ${ }^{9}$ sensitization of several tumor cells to tumor necrosis factor-alpha, ${ }^{10}$ and downregulation of X-linked inhibitor of apoptosis protein (XIAP) expression in leukemic cells. ${ }^{11}$ Based on the cell type, triptolide has been shown to induce different cell death mechanisms, including autophagy and apoptosis. ${ }^{12}$

Programmed cell death is of major importance in regulating organismal development, tissue homeostasis, and stress response and interconnects with cell survival and proliferation. ${ }^{13}$ Before the middle of the 20th century, there were various types of cell death observed. ${ }^{14}$ Despite that, just prior to 1990, apoptosis was synonymous with programmed cell death with the commitment to a physiologically controlled process. Recently, there has been a resurgence in studies using past knowledge of the other types of programmed cell death. ${ }^{14-18}$ In the case of metamorphosis in insects, it was demonstrated that programmed cell death and perhaps apoptosis can proceed without an early or controlling activation of an endonuclease. ${ }^{16,19}$ While many stimuli can act as triggers, the activation of lysosomal enzymes is the most likely candidate. ${ }^{16}$

Lysosomes, discovered over fifty years ago, are the major cell digestive organelles. ${ }^{20,21}$ They contain a number of hydrolases that are capable of breaking down nucleic acids, proteins, carbohydrates, and lipids. ${ }^{20}$ Today, it is clear that lysosomes and lysosomal proteases can be involved in apoptosis. Among lysosomal proteases, the role of cathepsins in cancer progression is especially well documented. ${ }^{22,23}$ Following their release into the cytosol, they cleave Bid and degrade antiapoptotic Bcl-2 proteins, thereby triggering the mitochondrial pathway of apoptosis, with lysosomal membrane permeabilization (LMP) being the critical step in this pathway. ${ }^{24} \mathrm{~A}$ recent report supports an apoptosis model involving lysosomalmitochondrial crosstalk induced by the combination of an epigenetic modulator and a DNA-damaging agent. ${ }^{25}$ Various insults, including oxidative stress and DNA damage, may lead to the limited release of cathepsins that culminate in the induction of apoptosis. Hsp70 has been implicated in playing an important role for inhibiting LMP to promote the survival of stressed cells. ${ }^{26}$ However, blocking cathepsins by small molecule inhibitors has been shown to significantly delay cancer progression in a number of mouse cancer models as well as to sensitize tumor cells to other chemotherapeutic agents. ${ }^{27}$ The release of cathepsins in excess may lead to cellular necrosis. ${ }^{28}$ Lysosomal-mediated apoptosis is still largely under investigation and not fully understood.

In this study, we demonstrate that triptolide induces morphological features characteristic of apoptosis, namely cell shrinkage and chromatin condensation. Furthermore, we show that cleaved poly (ADP-ribose) polymerase (PARP) and cleaved caspase-7 and cleaved caspase-9 levels were elevated in triptolide-treated cells. Lysosomal enzymatic activity and localization experiments revealed that these organelles participate in the cell death mediated by triptolide. We also show in cell fractionation studies that cytosolic levels of cathepsin B are increased during the early stages of apoptosis. These results suggest that triptolide-induced apoptosis in MCF-7 cells is mediated by lysosomes. To our knowledge, this study is the first to report a link between lysosomal hydrolases and triptolide's anticancer effects.

\section{Materials and methods Materials}

Triptolide $\left(\mathrm{C}_{20} \mathrm{H}_{24} \mathrm{O}_{6}\right.$, molecular weight $360.4,95 \%$ purity) was purchased from Calbiochem (EMD Millipore Corporation, Billerica, MA, USA) and dissolved in dimethyl sulfoxide ([DMSO] Sigma-Aldrich, St Louis, MO, USA). Stock solutions of triptolide in DMSO were stored at $-20^{\circ} \mathrm{C}$ at a concentration of $1 \mathrm{mg} / \mathrm{mL}$. For all control experiments, cells were treated with vehicle (DMSO) as indicated.

\section{Cell culture}

MCF-7 cells were purchased from American Type Culture Collection ([ATCC] Manassas, VA, USA). Cells were grown in Minimum Essential Medium ([MEM] Lonza Inc, Allendale, NJ, USA) and supplemented with $100 \mathrm{U} / \mathrm{mL}$ penicillin and $100 \mu \mathrm{g} / \mathrm{mL}$ streptomycin (ATCC), and 10\% fetal bovine serum (Atlanta Biologicals, Lawrenceville, GA, USA). All cells were grown in T-25 flasks (Life Technologies, Carlsbad, CA, USA) and incubated at $37^{\circ} \mathrm{C}$ in a humidified chamber at $95 \% \mathrm{O}_{2} / 5 \% \mathrm{CO}_{2}$. Cells were subcultured by washing with a 1× phosphate-buffered solution([PBS] $137 \mathrm{mM} \mathrm{NaCl}, 2.7 \mathrm{mM}$ $\mathrm{KCl}, 4.3 \mathrm{mM} \mathrm{Na}_{2} \mathrm{HPO}_{4} \times 7 \mathrm{H}_{2} \mathrm{O}, 1.4 \mathrm{mM} \mathrm{KH}_{2} \mathrm{PO}_{4}, \mathrm{pH}$ adjusted to $7.4)$ and using trypsin $(0.25 \%$ [w/v] trypsin- $0.53 \mathrm{mM}$ ethylene- 
diaminetetraacetic acid [EDTA] solution; Life Technologies). DU145 prostate cancer cell line was also purchased from ATCC and used as a positive control for the caspase- 3 immunoblotting assay. DU145 cells were grown in the same conditions as described above for MCF-7 cells.

\section{Hoechst staining}

Cells were treated in the presence or absence of $10 \mathrm{ng} / \mathrm{mL}$ (median lethal dose $\left[\mathrm{LD}_{50}\right]$ ) triptolide for 24 hours at $37^{\circ} \mathrm{C}$ and then with $1 \mathrm{mg} / \mathrm{mL}$ of DNA fluorochrome bisbenzimide (Hoechst 33258; Sigma-Aldrich) for 15 minutes at $37^{\circ} \mathrm{C}$ in the dark. Images were captured using the $\operatorname{EVOS}^{\circledR}$ FL fluorescence microscope (Life Technologies). The percentage of apoptotic cells (cells with nuclear condensation) was determined by examining at least 200 cells per condition in five randomly selected fields at $400 \times$ magnification.

\section{Assessment of cell viability}

To test for apoptosis, the 3-[4,5-dimethylthiazol-2-yl]-2,5diphenyltetrazolium bromide (MTT) reduction assay (Sigma-Aldrich) was used. Dissolved MTT is converted to an insoluble purple formazan by cleavage of the tetrazolium ring by dehydrogenase enzymes of living cells. ${ }^{29}$ Stock solutions of MTT were prepared in MEM at a concentration of $5 \mathrm{mg} / \mathrm{mL}$. Cells were treated in 6-well plates with varying concentrations of triptolide $(1 \mathrm{ng} / \mathrm{mL}, 5 \mathrm{ng} / \mathrm{mL}, 10 \mathrm{ng} / \mathrm{mL}$, $15 \mathrm{ng} / \mathrm{mL}$, and $20 \mathrm{ng} / \mathrm{mL}$ ) for 24 hours. After this incubation period, MTT $(0.2 \mathrm{~mL})$ was added to each well and the cells were incubated for 4 hours at $37^{\circ} \mathrm{C}$ in the dark. The medium was then removed and the converted dye was solubilized with the addition of acidic isopropanol $(0.1 \mathrm{~N} \mathrm{HCl}$ (hydrochloric acid) in absolute isopropanol). Absorbance, which was proportional to cell viability, was measured at $570 \mathrm{~nm}$ with background subtraction at $660 \mathrm{~nm}$. All readings were performed in triplicate.

\section{Acid phosphatase (AP) assay}

A biochemical assay (Sigma-Aldrich Procedure No 104) was used to measure the activity of AP, a marker enzyme for lysosomes. ${ }^{19}$ Cells were treated in the presence or absence of $10 \mathrm{ng} / \mathrm{mL}$ triptolide for 24 hours at $37^{\circ} \mathrm{C}$. Cell lysates were then transferred to a $0.9 \% \mathrm{NaCl}$ solution, and centrifuged for 5 minutes at $10,000 \times g$. The $g$ should be italicized. The reaction mixture consisted of $0.5 \mathrm{~mL}$ p-nitrophenol phosphate (substrate), $0.5 \mathrm{~mL} 90 \mathrm{mM}$ citrate buffer ( $\mathrm{pH} 4.8$ ), and $0.1 \mathrm{~mL}$ of lysates and was incubated for 30 minutes at room temperature. The reaction was terminated with the addition of $0.5 \mathrm{~mL} 0.1 \mathrm{~N} \mathrm{NaOH}$. In alkali, liberated p-nitrophenol was measured spectrophotometrically at $410 \mathrm{~nm}$. Units of enzyme activity were determined from the calibration curve obtained by measuring the amount of color produced.

\section{Acridine orange}

Cells were grown on coverslips and incubated for 24 hours in the presence or absence of triptolide. Stock solutions of acridine orange were prepared $(5 \mathrm{mg} / \mathrm{mL})$. Cells were incubated for 15 minutes in the dark with acridine orange (final concentration, $2.5 \mu \mathrm{g} / \mathrm{mL}$ ) at $37^{\circ} \mathrm{C}$. Cells were then rinsed with $1 \times$ PBS and coverslips were mounted using Crystal Mount (Sigma-Aldrich). Images were captured using the EVOS FL fluorescence microscope.

\section{LysoTracker ${ }^{\circledR}$ staining}

Cells were grown on 6-well plates and incubated for 24 hours in the presence $(10 \mathrm{ng} / \mathrm{mL})$ or absence of triptolide. $1 \mathrm{mM}$ stock solutions of LysoTracker Green DND-26 (Molecular Probes; Life Technologies) were prepared to $1 \mu \mathrm{M}$ working solution with warm culture media. Cells were incubated for 1.5 hours in the dark with LysoTracker working solution at $37^{\circ} \mathrm{C}$. Cells were then rinsed with $1 \times$ Tris-buffered saline (TBS) and observed using a Motic AE31 fluorescence microscope (Causeway Bay, Hong Kong) and SPOT imaging software (v 4.7.0.35; SPOT Imaging Solutions, Sterling Heights, MI, USA).

\section{Cell lysis and protein quantification Whole-cell lysate}

Cells were treated with varying concentrations of triptolide for 24 hours in 6-well plates. Both culture medium and adherent cells were collected in $15 \mathrm{~mL}$ tubes, and samples were centrifuged at $3,000 \times g$ for 5 minutes. Cells were rinsed once with $1 \times$ cold PBS (from 10X PBS; Thermo Fisher Scientific, Waltham, MA, USA); $200 \mu$ L of SoluLyse-M (Genlantis, San Diego, CA, USA) with $1 \%$ protease inhibitor cocktail and 1\% EDTA Solution (Thermo Fisher Scientific) were added to each, and incubation occurred at room temperature for 10 minutes. The lysates were then collected in microcentrifuge tubes and centrifugation occurred at $14,000 \times g$ for 5 minutes. The clarified lysates were transferred into fresh tubes for further analysis.

\section{Cytosolic/particulate separation}

Cells were treated with varying concentrations of triptolide for 3 hours (early apoptotic stage) and 24 hours (late apoptotic stage) in T-25 flasks. Both culture medium and adherent cells were collected in $15 \mathrm{~mL}$ tubes, and samples were centrifuged 
at 3,000 $\times g$ for 5 minutes. Supernatants were decanted off and precipitates were rinsed with $1 \times$ cold PBS and centrifuged again. After supernatants were decanted off, we followed the manufacturer's protocol for the Cytosol/Particulate Rapid Separation Kit (BioVision, Milpitas, CA, USA).

The Pierce BCA Protein Assay Kit (Thermo Fisher Scientific) was used to determine protein concentration. Samples were then analyzed at $562 \mathrm{~nm}$ using the Nano-Drop 2000 Spectrophotometer (Thermo Fisher Scientific). A standard curve was generated and the protein concentrations of the unknown samples were determined.

\section{Western blot analysis}

Lysates were prepared using Laemmli Sample Buffer (Bio-Rad Laboratories, Hercules, CA, USA). Samples were separated by $10 \%$ EZRun protein gel solution (Thermo Fisher Scientific) and electrophoresed at 150 volts until the dye front was at the end of the gel. Proteins were transferred onto polyvinylidene difluoride membranes (PVDF) membranes using a Trans-Blot Turbo Blotting System (Bio-Rad Laboratories). After the blocking, membranes were incubated in the appropriate dilution of primary antibodies in $1 \mathrm{X}$ Trisbuffered saline $/ 0.1 \%$ Tween 20 (TBST) overnight at $4^{\circ} \mathrm{C}$ with gentle shaking. Anti-caspase-9 and anti-caspase-7 antibodies (cleaved: Cell Signaling, Danvers, MA, USA; full length: Santa Cruz Biotechnology, Dallas, TX, USA), anti-PARP antibodies (Cell Signaling), and anti-cathepsin B antibody (AbCam, Cambridge, MA USA) were used. Anti- $\beta$-actin antibody (Santa Cruz Biotechnology) was used as a loading control. Blots were washed three times for 5-10 minutes per wash in $1 \times$ TBST followed by incubation in the appropriately diluted horseradish peroxidase-conjugated anti-rabbit (or anti-mouse) immunoglobulin G secondary antibodies (Cell Signaling or Santa Cruz Biotechnology) at room temperature for 1 hour. The blots were washed three times in $1 \times$ TBST for 5 minutes. The SuperSignal West Pico Chemiluminescent Substrate kit (Thermo Fisher Scientific) was used for antigen detection. Images were obtained using a film processor SRX101 A (Konica Minolta Medical Imaging USA, Newark, NJ, USA). Band intensities were measured using the Image $\mathrm{J}$ 1.46r software (National Institutes of Health [NIH], Bethesda, MD, USA).

\section{Statistical analyses}

Data were presented as means \pm standard error of the mean. Student's $t$-test was performed to evaluate differences between treated and control samples. Values were considered statistically significant at $P<0.05$.

\section{Results \\ Cellular morphology of triptolide-treated MCF-7 breast cancer cells}

Firstly, we confirmed whether triptolide, which is an apoptotic stimulus in various tumor cell lines, ${ }^{9-11,30}$ induces apoptosis in MCF-7 cells. Phase-contrast microscopy was used after treatment with various concentrations of triptolide for 24 hours. Uniform normal adhesive and colonized cells were observed in the control group (Figure 1A), whereas significant reduction in colony formation of the experimental groups could be observed in a dose-dependent manner (Figure 1B-E). We observed that whole cells shrank and a part of the cells detached with increasing triptolide concentrations, but there were few instances of cellular blebbing. Meanwhile, typical cellular blebbing was observed in triptolide-treated DU145 cells (data not shown). These results suggest that triptolide can induce cell death independent of cytoplasmic blebbing as has been demonstrated with other drugs in MCF-7 cells..$^{31,32}$

\section{Effect of triptolide on chromatin condensation}

Chromatin condensation is a hallmark of apoptosis. To support the notion that triptolide induces apoptosis in MCF-7 cells, cells were treated in the presence or absence of triptolide and then stained with Hoechst 33258. Normal, flattened nuclear morphology was observed in control cells (Figure 2A), whereas round, shrunken cells displaying fragmented nuclei were detected in experimental cells (Figure 2B). The percentage of apoptotic cells in control and experimental cells was quantified (Figure 2C). These data add supportive evidence that triptolide treatment results in apoptosis in MCF-7 cells.

\section{Effect of triptolide on cell viability}

A previous study demonstrated that triptolide inhibits cell viability in MCF-7 cells in a dose- and time-dependent manner, ${ }^{33}$ and we sought to confirm these results. Reduced cell viability was quantitatively determined by MTT assay after the cells were treated with various concentrations of triptolide by spectrophotometric means. MCF-7 cells were treated in the presence or absence of triptolide at varying concentrations to determine if there was a dose-dependent and/or time-dependent relationship in conjunction with triptolide treatments. As seen in Figure 3A, triptolide inhibited proliferation of MCF-7 cells in a dose-dependent manner. The results indicate that cytotoxicity of triptolide in MCF-7 cells was significant when compared with 


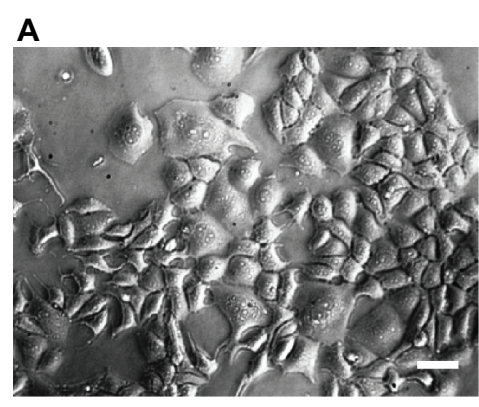

D

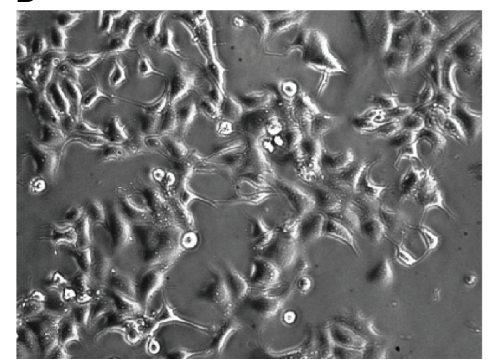

B

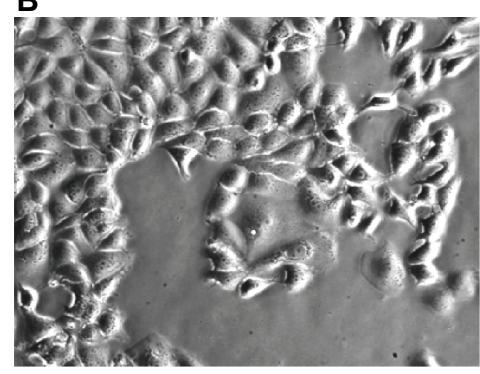

C

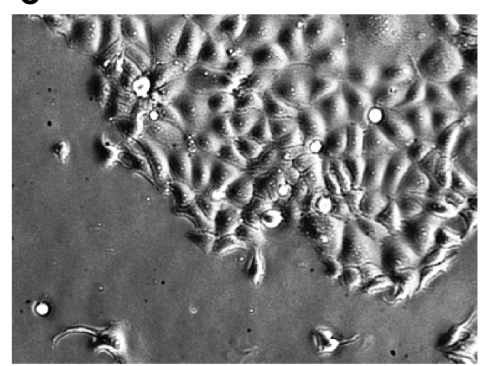

E

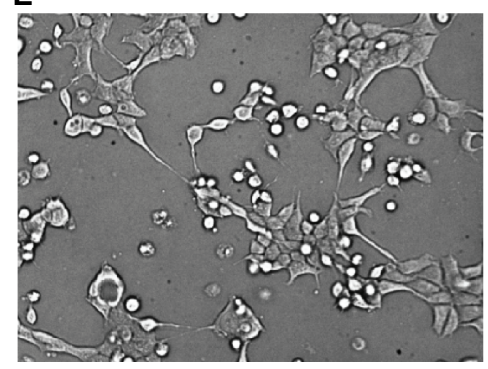

Figure I Phase-contrast micrographs of triptolide-treated MCF-7 cells incubated for 24 hours.

Notes: (A) Control MCF-7 cells showed the normal MCF-7 cell formation. (B) At $5 \mathrm{ng} / \mathrm{mL}$ and (C) at 10 ng/mL, triptolide-treated cells reveal increased numbers of cell detachment from the culture plate. (D) At $15 \mathrm{ng} / \mathrm{mL}$, triptolide-treated cells show more cells rounding with a substantial loss of cell-cell contact. (E) At $30 \mathrm{ng} / \mathrm{mL}$, most of the triptolide-treated cells are rounded and significant cell detachment was observed. Cell-cell contact remained but the number of viable cells was reduced. Representative phase-contrast images of at least three independent studies are shown. The scale bar is $50 \mu \mathrm{m}$.
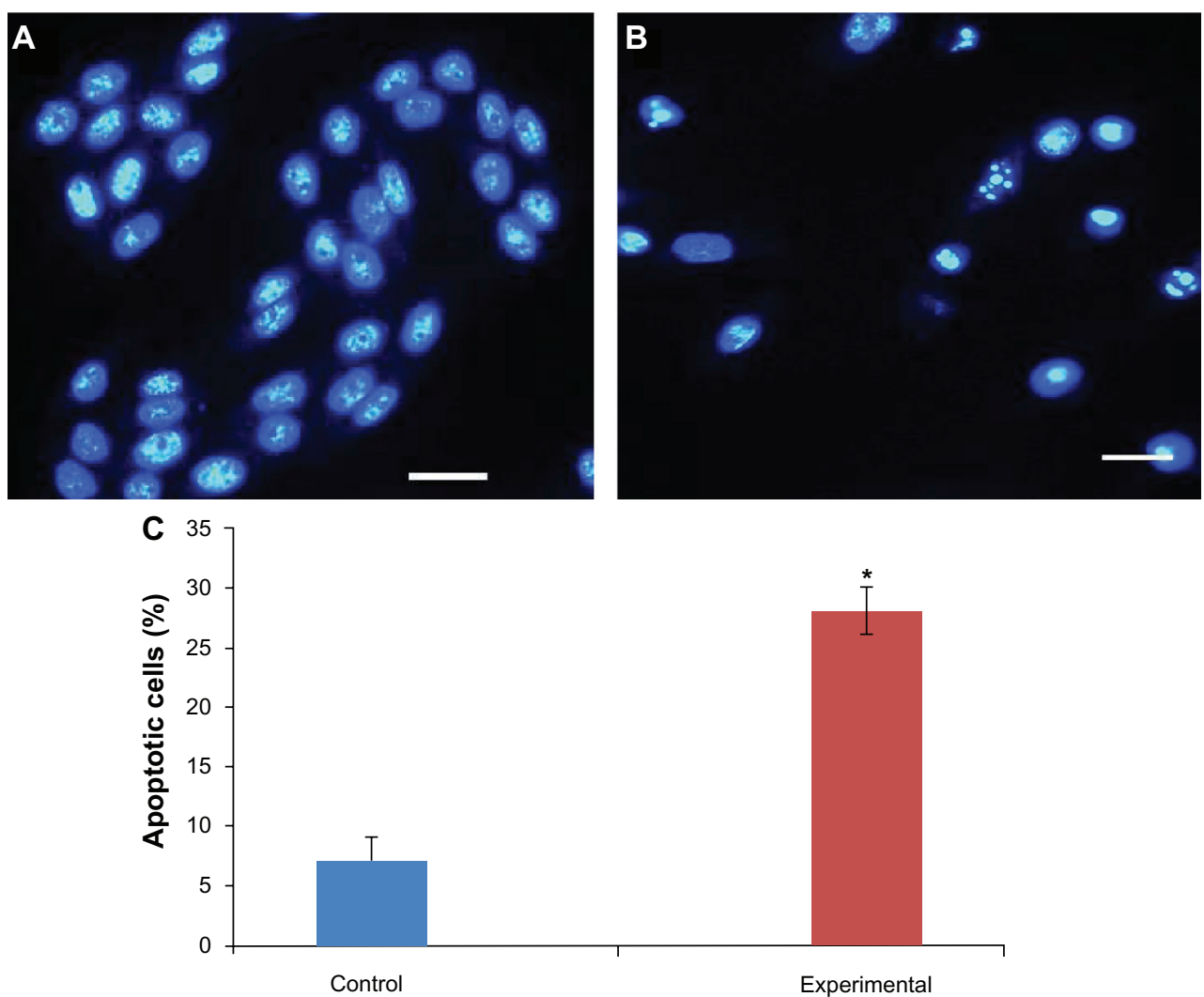

Figure 2 Effect of triptolide on chromatin condensation.

Notes: MCF-7 cells were treated in the absence (A) or presence (B) of $10 \mathrm{ng} / \mathrm{mL}$ triptolide for 24 hours and then exposed to Hoechst dye. (C) The percentage of apoptotic cells was determined by counting a minimum of 200 cells/treatment group in each experiment. (A) Normal nuclear morphology is observed in control cells. (B) In contrast, shrunken, fragmented, and condensed nuclei were observed in triptolide-treated cells. A minimum of 200 cells/treatment group were counted in each experiment. *Significant differences from control group $(P<0.0002)$. The images are representative of at least three independent experiments. The scale bar is $100 \mu \mathrm{m}$. 
A

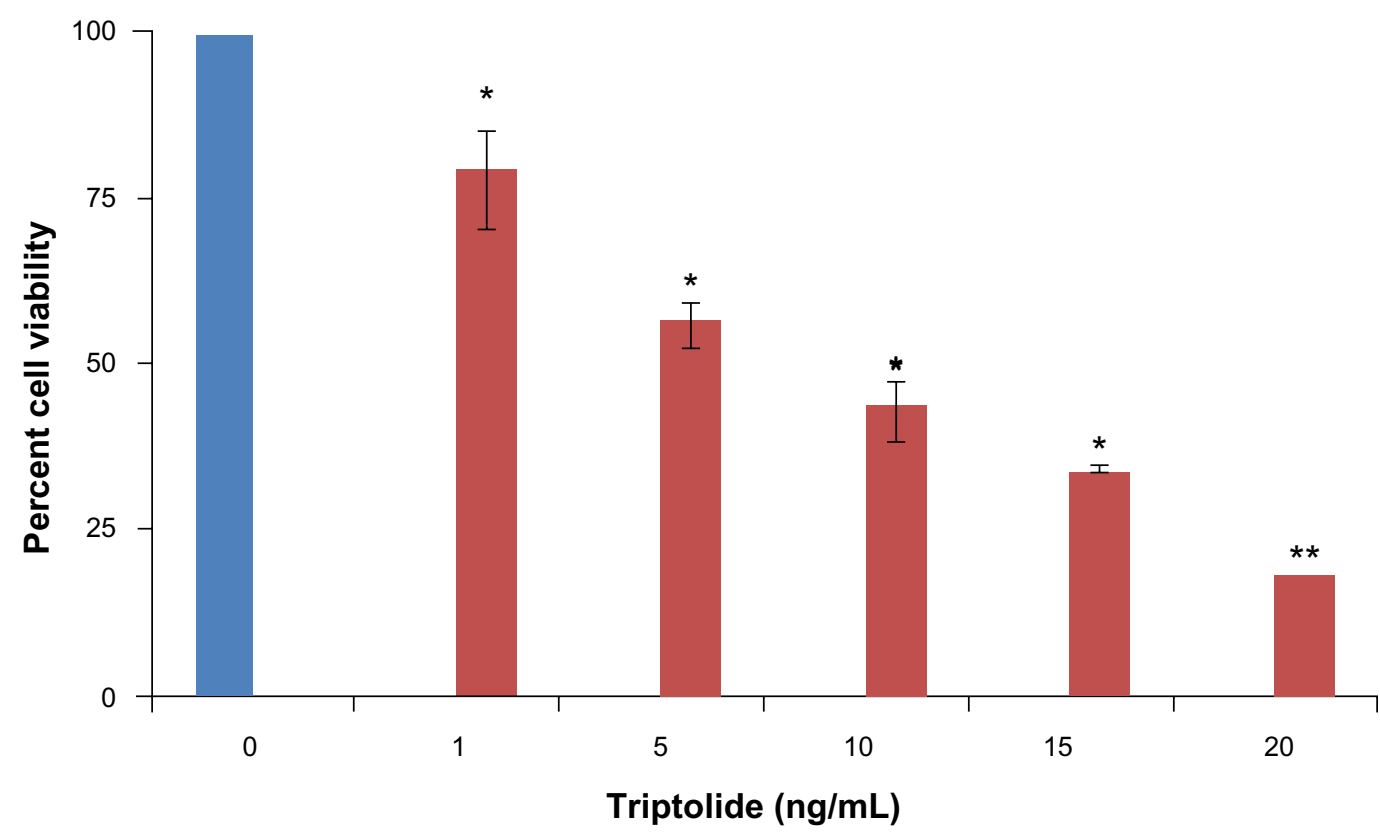

B

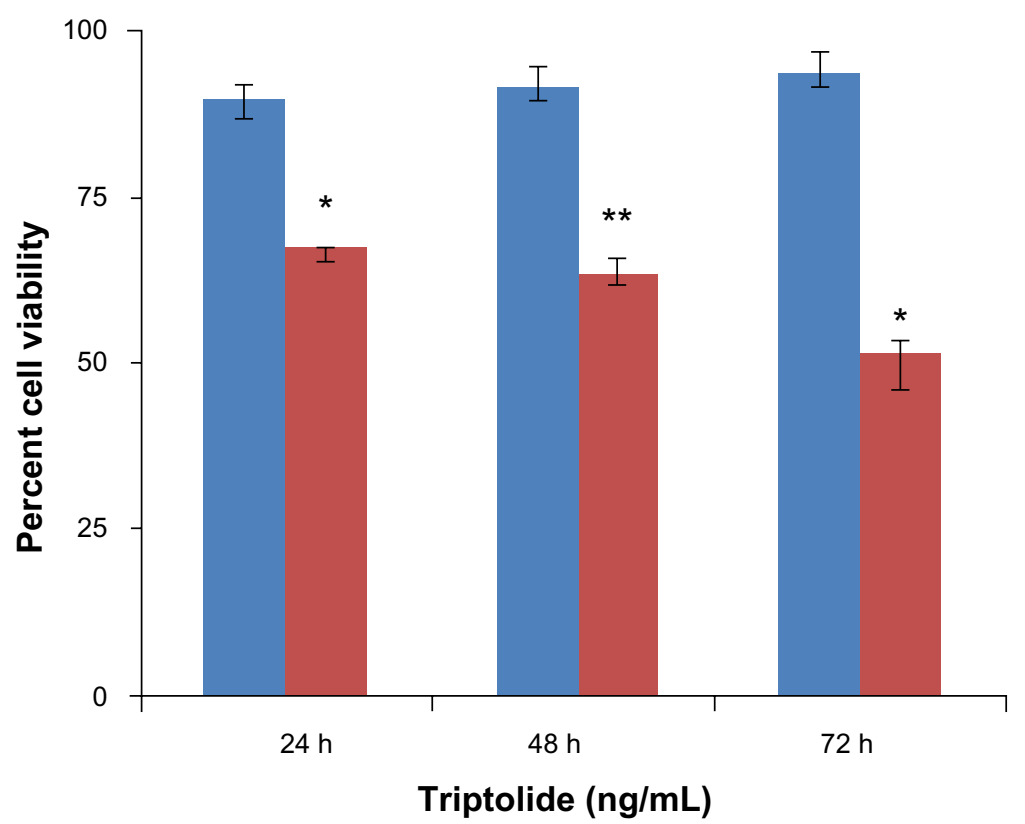

Control

Experimental

Figure 3 Cell death determination by MTT assay.

Notes: MCF-7 cells were plated in triplicate and treated with varying concentrations of triptolide $(\mathbf{A})$ or for various incubation periods with $10 \mathrm{ng} / \mathrm{mL}$ triptolide $(\mathbf{B})$ and the absorbance values were recorded. Values shown are means \pm SEM of three independent experiments. Values were normalized to values obtained in vehicle-treated (control) cells and expressed as a percentage of controls. $* P<0.001$; $* * P<0.0001$.

Abbreviations: MTT, 3-[4,5-dimethylthiazol-2-yl]-2,5-diphenyltetrazolium bromide; SEM, standard error of the mean.

control cells. The MTT assay result shows dose-dependent death of MCF-7 cells with triptolide treatment. From these data, we chose the $10 \mathrm{ng} / \mathrm{mL}$ concentration of triptolide as our $\mathrm{LD}_{50}$ for all future experiments. Furthermore, to examine whether triptolide had an effect over an extended period of time, studies were conducted for 24,48 , and 72 hours. The increase in cell death was directly proportional to longer incubation periods (Figure 3B). Taken together, these results show that MCF-7 cells were efficiently killed by triptolide in a dose- and time- dependent manner. 


\section{Effect of triptolide on the expression of pro-apoptotic proteins}

To further elucidate whether apoptosis mediates MCF-7 cell death, we investigated expression levels of pro-apoptotic proteins, PARP, caspase-9, and caspase-7, using western blotting. In general, caspase-3 is a major component of the apoptotic signaling pathway. But MCF-7 has an inherent lack of caspase- $3,{ }^{31,32}$ and the $35 \mathrm{kDa}$ full-length caspase- 3 was not detected in MCF-7 cells, although it was detected in control DU145 prostate cancer cells by western blotting (data not shown). The expression levels of the full-length PARP band decreased in a dose-dependent manner with triptolide concentration, and a band representing the cleaved PARP increased in a dose-dependent manner (Figure 4). Full-length caspase-9 and caspase-7 protein levels were also downregulated in experimental cells in a dose-dependent manner. In contrast, cleaved caspase-9 and cleaved caspase-7 protein levels increased in a dose-dependent manner (Figure 4). Taken together, these results indicate that triptolide induces a dose-dependent activation of pro-apoptotic proteins in caspase-3-deficient MCF-7 cells.

\section{Lysosomal enzymatic activity and localization}

We quantified the activity of lysosomal enzymes by monitoring the activity of AP, a marker enzyme for lysosomes. ${ }^{19}$ MCF-7 Cells were seeded in 12-well plates for 24 hours and then incubated at various times in the presence or absence of $10 \mathrm{ng} / \mathrm{mL}$ triptolide. This concentration was chosen as the
$\mathrm{LD}_{50}$ from our MTT experiments. AP activity was elevated after 24 and 72 hours in experimental cells (Figure 5). This observation has also been demonstrated in the labial glands of Manduca sexta, where lysosomal AP activity increased during early larval to pupal metamorphosis and leveled off during mid-metamorphosis; ultimately, the bulk of the cytoplasm was engulfed by autophagic vacuoles. ${ }^{19}$

To further demonstrate that triptolide induces atypical apoptosis via acidic organelles (eg, lysosomes), cells were stained with acridine orange, a fluorescent dye that accumulates in acidic organelles. Control cells displayed distinct red fluorescence in an acidic environment, the lysosomes, (Figure 6A) and a weak, green fluorescence in a neutral environment, the cytosol, (Figure 6B). In contrast, in experimental cells, red fluorescence was reduced (Figure 6D) and green fluorescence was maximally increased (Figure 6E), which might suggest that advanced lysosomal rupture resulted in triptolide-treated cells. Merged images of control and experimental cells are shown in Figures 6C and $6 \mathrm{~F}$, respectively.

Finally, we observed the morphology of lysosomes using LysoTracker Green, which concentrates in intact lysosomes and emits green fluorescence (Figure 7). After 24 hours from cell seeding, cells were incubated for 24 hours in the presence or absence of $10 \mathrm{ng} / \mathrm{mL}$ triptolide. We found that controls had a majority of healthy and adhesive cells, which displayed a punctate green fluorescence staining pattern (Figure 7A). In contrast, a significant reduction in cell number and increased cell detachment were observed in triptolide-treated cells

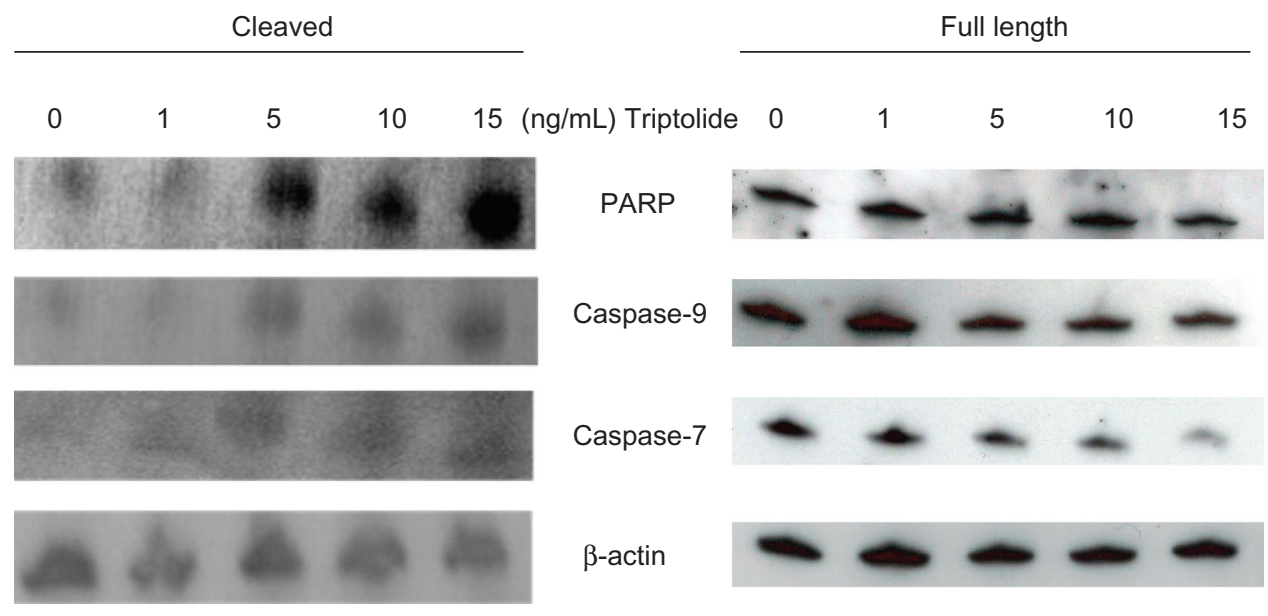

Figure 4 Effect of triptolide on pro-apoptotic proteins expression levels.

Notes: Whole-cell lysates of MCF-7 cells, untreated (control) or treated with various concentrations of triptolide for 24 hours, were subjected to I0\% SDS-PAGE, followed by western blot analysis using anti- PARP, caspase-9, caspase-7, or $\beta$-actin antibody. A representative blot from at least triplicate experiments is shown. (A) Full-length PARP (I $16 \mathrm{kDa}$ ), caspase-9 (46 kDa), and caspase-7 (34 kDa) bands decreased dose-dependently with triptolide concentration. (B) Cleaved PARP (89 kDa), caspase-9 (35 kDa), and caspase-7 $(20 \mathrm{kDa})$ were identified as increasing dose-dependently with triptolide concentration. The blots are representative of at least three independent experiments. $\beta$-actin reflects the loading control.

Abbreviations: PARP, poly(ADP-ribose) polymerase; SDS-PAGE, sodium dodecyl sulfate polyacrylamide gel electrophoresis. 


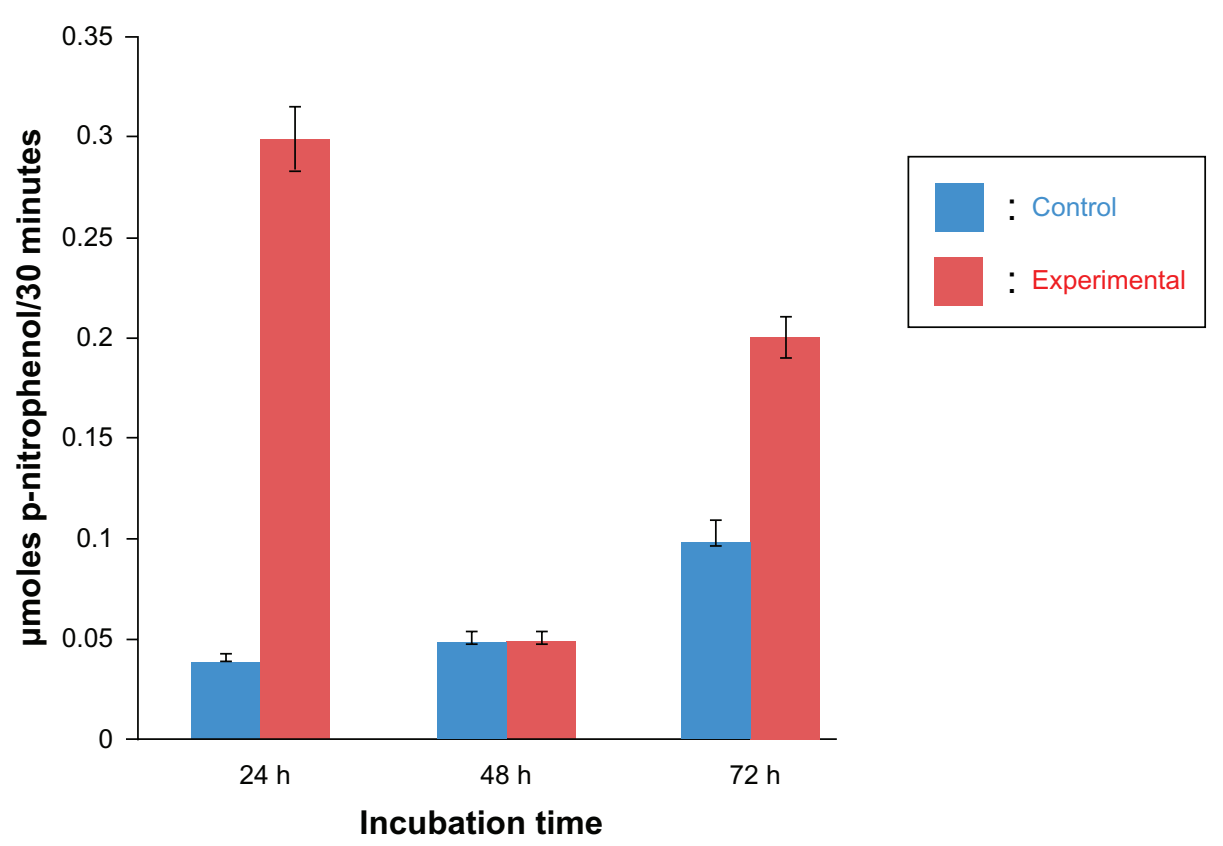

Figure 5 Effect of triptolide on lysosomal enzyme activity.

Notes: MCF-7 cells were treated in the presence or absence (control) of $10 \mathrm{ng} / \mathrm{mL}$ triptolide for the indicated incubation times shown on the $\mathrm{x}$-axis. The values represent means \pm standard error of the mean of at least three independent experiments. Total activity of acid phosphatase is expressed as $\mu$ moles $\mathrm{p}$-nitrophenol released per 30 minutes, as indicated on the $y$-axis. Blue bars represent control cells and red bars represent experimental cells.

(Figure 7B). Furthermore, there was increased uptake of LysoTracker Green in experimental cells compared to control cells (Figure 7B). These results suggest that triptolide exposure results in modulation of lysosomal membrane integrity.

\section{Effect of triptolide on the expression of lysosomal proteins}

To further confirm our hypothesis that triptolide induces programmed cell death triggered by lysosomal disintegration, the leakage of lysosomal enzymes in the cytosolic fractions was investigated.

As described in the "Materials and methods" section, MCF-7 cells were seeded for 24 hours and then incubated in the presence or absence of $10 \mathrm{ng} / \mathrm{mL}$ triptolide. Each whole-cell lysate was separated into cytosolic and particulate fractions according to the manufacturer's instructions. We investigated the protein expression levels of the cysteine protease cathepsin B, as an indicator of the

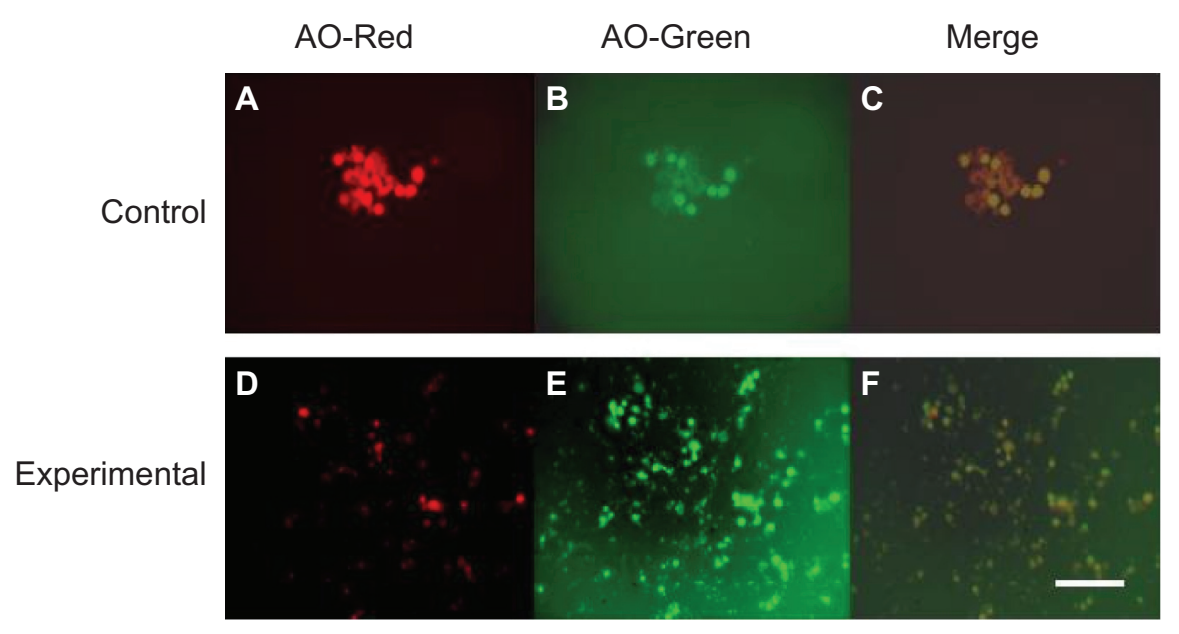

Figure 6 Effect of triptolide on localization of lysosomes.

Notes: Cells were treated in the absence (A-C) or presence (D-F) of $10 \mathrm{ng} / \mathrm{mL}$ triptolide for 24 hours and then stained with acridine orange (AO). Magnification: $400 \times$ in each field. Shown are representative images of three independent experiments. The scale bar represents $100 \mu \mathrm{m}$. The corresponding merged images are shown on the right (C and F). 


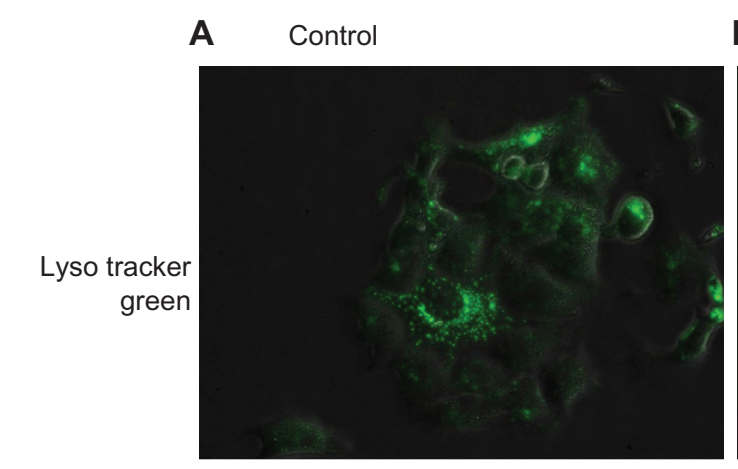

\section{B Experimental}
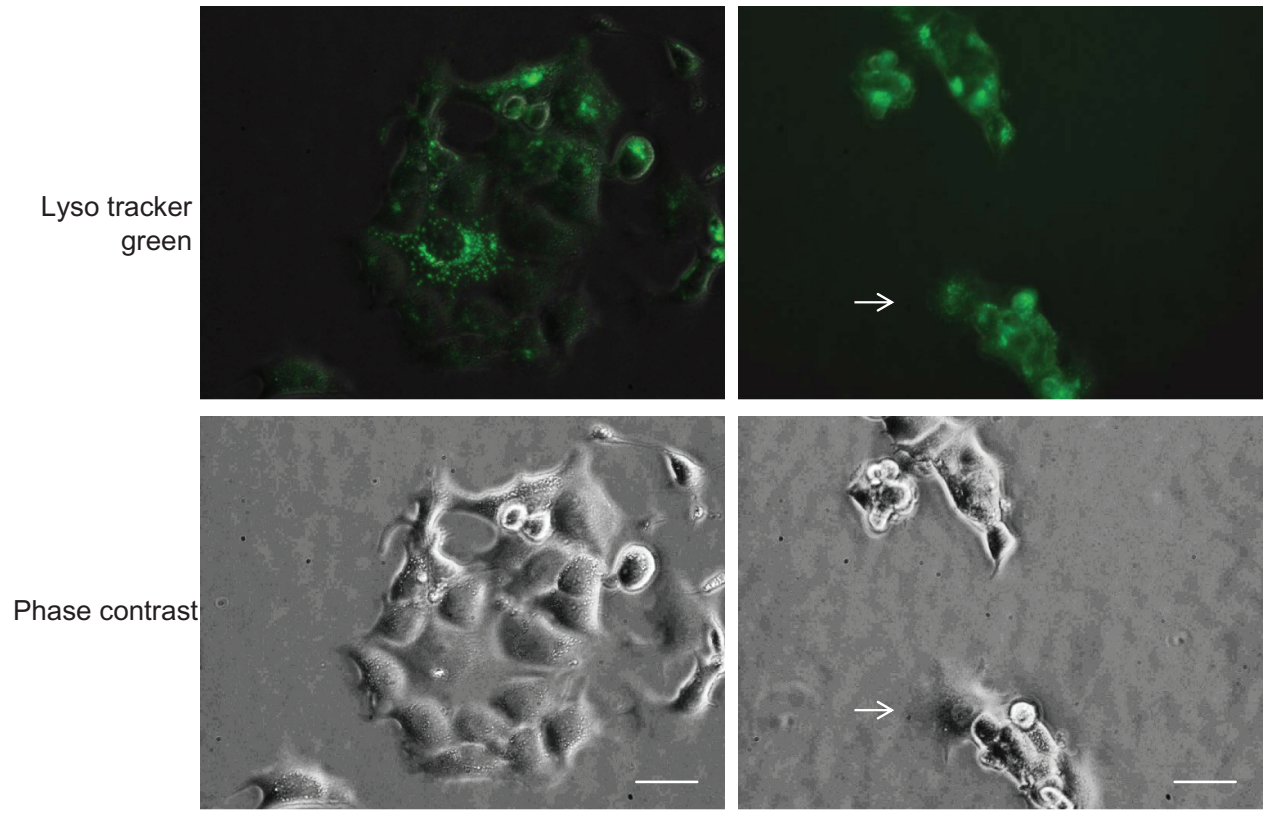

Figure 7 Morphological comparison of lysosomes.

Notes: MCF-7 cells were treated in the absence $(\mathbf{A})$ or presence $(\mathbf{B})$ of $10 \mathrm{ng} / \mathrm{mL}$ triptolide for 24 hours and then stained with LysoTracker ${ }^{\circledR}$ Green (Molecular Probes; Life Technologies, Carlsbad, CA, USA). The corresponding merged images are shown in the upper panels. Phase-contrast micrographs are shown in the lower panels. Magnification: $400 \times$ in each field. The arrow indicates an aggregation of lysosomes in experimental cells. Shown are representative images of three independent experiments. The scale bar represents $50 \mu \mathrm{m}$.

leakage, using the MCF-7 cytosolic fractions analyzed by western blotting. Each sample included two time points, 3 hours and 24 hours after drug treatment. In general apoptosis, 3 hours might be an early apoptotic stage and 24 hours might be a late stage. In Figure 8A, mature cathepsin B protein levels were compared between cytosolic and total fractions of untreated MCF-7 cells and $10 \mathrm{ng} / \mathrm{mL}$ triptolide-treated MCF-7 cells. The data support the fact that cathepsin B leaked into the cytosol 3 hours after drug treatment and experimental cytosolic fractions contained more cathepsin B than control samples at both time points. Total protein fractions also showed a band corresponding to cathepsin B, which indicates that triptolide does not just increase total cathepsin B. In Figure 8B, an increase in cathepsin B protein levels from 3 hours to 24 hours in the cytosolic fractions was detected by quantitative analysis. These results suggest that triptolide promotes leakage of lysosomal hydrolases into the cytosol. The release of lysosomal enzyme cathepsin B into the cytosol confirmed our LysoTracker Green results that triptolide affects lysosomal integrity.

In summary, our results suggest that programmed cell death and atypical apoptosis, in MCF-7 cells, as a result of triptolide exposure, is dependent on LMP.

\section{Discussion}

Triptolide, an extract of Tripterygium wilfordii Hook F, has been widely used in the People's Republic of China for the treatment of inflammatory and autoimmune diseases for centuries. In addition to its anti-inflammatory and immunosuppressive effects, anticancer effects have also been reported in recent years. ${ }^{10,11,34}$ Triptolide can covalently interact with and inhibit the general transcription factor TFIIH component XPB, explaining its transcriptional effects. ${ }^{8}$ The expression of metalloproteinase 10 (ADAM10) is increased in several tumors, including leukemia, and is involved in malignant cell growth and cancer progression. ADAM10 is a novel target of triptolide; inhibition of ADAM10 by triptolide might be another mechanism by which triptolide inhibits tumorigenesis. ${ }^{34}$ Polycystin-2 (PC2) has been identified as a candidate target for the therapeutic action of triptolide and an association between PC2 expression and sensitivity to triptolide-induced growth arrest/ cell death has been observed. ${ }^{35}$ Triptolide has been reported to be the first known inhibitor of dCTP pyrophosphatase 1 (DCTPP1).${ }^{36}$ DCTTP1 is postulated to be a gatekeeper enzyme, protecting RNA or DNA against incorporation of noncanonical nucleotide triphosphates. However, it is also possible that the antitumor effects of triptolide may be explained by some other, yet unidentified, mechanisms. The fact that multiple 


\section{A Cytosolic fraction}

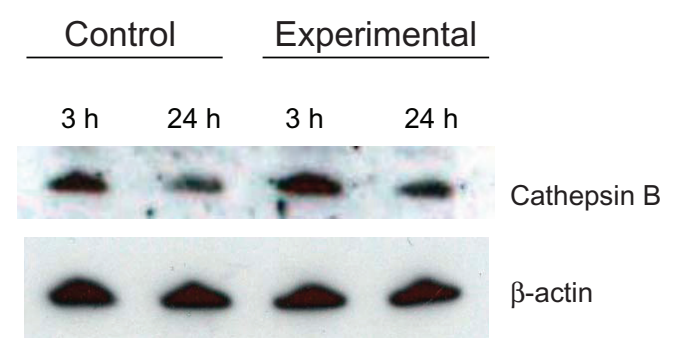

Whole cell lysate

\section{Control Experimental}

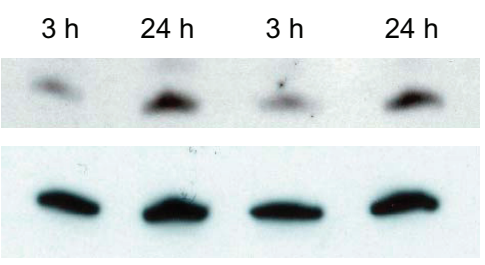

B

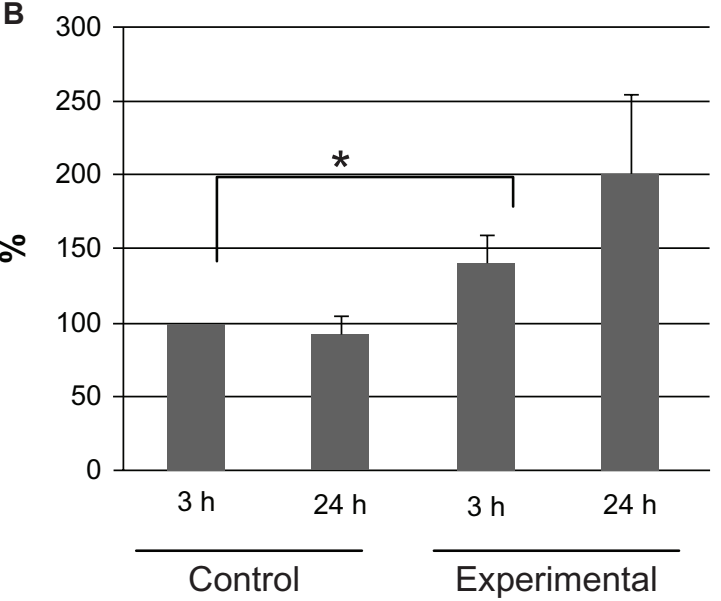

Figure 8 Lysosomal protein expression levels on cytosolic fraction of MCF-7 cells.

Notes: Cytosolic fractions of MCF-7 cells, untreated (control) or treated with $10 \mathrm{ng} / \mathrm{mL}$ triptolide (triptolide) for 3 or 24 hours, were investigated by western blot analysis. Western blot images are representative of three independent studies. $\beta$-actin reflects loading control. (A) Left: after 3-hour incubation (which is generally an early stage of apoptosis), triptolide-treated samples express elevated levels of the mature, active form of cathepsin B (3I kDa) in cytosolic fractions compared to controls. Right: unfractionated samples. (B) Using cathepsin B protein level images of cytosolic fraction, values were normalized to values obtained in controls and expressed as a percentage of controls. At the 3-hour time point, MCF-7 cytosol has more cathepsin B induced by triptolide. The values represent means \pm standard deviation of at least three independent experiments. Student's $t$-test was performed to evaluate differences. Values were considered statistically significant at $* P<0.05$.

molecular targets participate in triptolide's pharmacological functions support the notion that triptolide can be an effective anticancer agent against cells and tumors that lack caspase-3.

Among the various in vitro cell line models available for breast cancer, the MCF-7 cell line presents distinctive properties that may help shed new light on the mechanism of action of triptolide. In particular, MCF-7 is an estrogen receptor-positive cell line that lacks caspase- 3 and beclin-1; ${ }^{37,38}$ thus, it represents a cell model with compromised apoptotic machinery and low autophagic activity that might influence cellular response to anticancer drug treatment. We propose that the deletion of caspase- 3 in tumors or cells will not limit triptolide's usefulness because other mechanisms are at work, such as autophagy. Triptolide induces apoptosis in various cancer cells and, thus far, very little is known about the effect of triptolide on MCF-7 cells, except that triptolide exposure results in an increase in p53 expression, ${ }^{33}$ a decrease in estrogen receptor- $\alpha$ expression, ${ }^{33}$ a decrease in ADAM10 expression, ${ }^{34}$ and focal adhesion kinase cleavage. ${ }^{30}$

A previous study suggested that triptolide may regulate lysosomal-mediated apoptosis in MCF-7 breast cancer cells. ${ }^{39}$ In the present study, we demonstrate that triptolide's cytotoxicity is dose- and time-dependent in MCF-7 cells, as examined by morphology (Figure 1), Hoechst staining (Figure 2), MTT assay (Figure 3), and western blot analysis (Figure 4). Our MTT data are in agreement with a previous report by Liu et al. ${ }^{33}$ Regarding triptolide-induced morphology, MCF-7 cells displayed less cytoplasmic blebbing (Figure 1), and the pattern of pro-apoptotic protein expression levels (Figure 4) was similar to that of staurosporine-treated MCF-7 cells. ${ }^{32}$ PARP and procaspase- 9 and -7 protein levels were downregulated in experimental cells in a dose-dependent manner, and cleaved PARP, caspase-9, and caspase-7 protein levels increased in a dose-dependent manner (Figure 4). Active caspase-9 is an initiator protease that complexes with Apaf-1 and cytochrome c to form the apoptosome. ${ }^{40}$ 
Caspase-7 has been shown to cleave PARP-1 in apoptotic MCF-7 cells, ${ }^{41}$ while a more recent study revealed that caspase-7 uses an exosite to promote PARP proteolysis. ${ }^{42}$ Therefore, we concluded that MCF-7 cell death as a result of triptolide exposure is atypical apoptosis.

Before the discovery of the caspase family of proteases, most cell deaths were considered to be lysosomal"3 or "type II," 15 requiring activation of the lysosomal compartment. In insects, cell death at metamorphosis is typically autophagic, and blocking autophagy is a pupariation lethal. ${ }^{45}$ This autophagic type of cell death may also be used in situations in which conventional apoptosis is blocked or limited by mutation or other controls, as in MCF7 cells, which lack caspase-3, or in which massive cell death overwhelms the ability of phagocytes to clear the terrain. ${ }^{46}$ Zakeri et al reported that in metamorphosing, secretory cells and under conditions where the majority of cells die, the bulk of the cytoplasm is consumed by expansion of the lysosomal system well before nuclear collapse is manifested. ${ }^{16}$ In the current study, we demonstrate that triptolide induces programmed cell death in MCF-7 cells that is presumably characterized by a leakage of lysosomal enzymes into the cytosol.

We report here that triptolide induces lysosomal-mediated apoptosis in MCF-7 cells. Figure 5 illustrates the activity of AP Halaby et al previously used AP to monitor apoptosis in degenerating $M$. sexta labial glands during the larval to pupal metamorphosis. ${ }^{19}$ Others have used this enzyme to measure cell death in Drosophila salivary glands as well as insect intersegmental muscles. ${ }^{47,14}$ AP activity was elevated after 24 and 72 hours in experimental cells (Figure 5). These results are supported by our previous study examining AP activity in the labial gland of Manduca during the larval to pupal molt. ${ }^{48}$ The relatively high levels of AP activity in control cells at 72 hours may be explained by the fact that activities of specific lysosomal hydrolases are higher in tumor cells than in the corresponding normal cells. ${ }^{49}$ These results suggests that triptolide activates lysosomes. Next, experimental cells stained with the vital dye acridine orange displayed neutral cytosolic staining, which did not occur in control cells (Figure 6C and F). Acridine orange concentrated in lysosomes emits a granular red fluorescence, whereas, in the cytosol, it emits a diffuse green fluorescence. ${ }^{50}$ These data suggest that triptolide mediated a reduction in red fluorescence while an increased diffuse cytosolic green fluorescence indicated a relocation of acridine orange from the lysosomes to the cytosol following a change in lysosome permeability. This provides supporting evidence for our hypothesis that triptolide modulates LMP. Similarly, exposure of cells to triptolide resulted in an increase in the accumulation of the lysosomotropic probe LysoTracker Green (Figure 7B).

LysoTracker Green staining also demonstrated that triptolide-treated cells displayed diffuse and intense staining, whereas staining was punctate and reduced in control cells (Figure 7).

Finally, expression levels of cathepsin B in MCF-7 cytosolic fractions supported susceptibility to lysosomal permeabilization. Elevated cathepsin B was detected at the early stage of cell death (3 hours post-triptolide-treatment). Decreased expression of cathepsin B was detected in control cells (Figure 8). Altogether, these results suggest that triptolide affects LMP. The resulting change in lysosomal membrane permeability in turn leads to leakage of the lysosomal hydrolases into the cytosol, where they can trigger the apoptotic cascade by activating proteins such as $\mathrm{Bid}^{23,24}$ This notion, that lysosomal rupture may be an upstream event during some instances of apoptosis, is supported by Figure 8 and is also reinforced by work from others. ${ }^{51-53}$ These findings suggest that lysosomal destabilization might play an integral part in programmed cell death via the intrinsic pathway.

Increasing evidence suggests that lysosomes are important mediators of programmed cell death. In autophagic cell death, lysosomes fuse with autophagosomes to form autophagolysosomes, by which their contents are degraded. ${ }^{54}$ In apoptosis, cathepsins are released from lysosomes into the cytoplasm and trigger a cascade of intracellular degradation. ${ }^{53,55,56}$ The involvement of lysosomes in both programmed cell death pathways ${ }^{55-57}$ may suggest an involvement of cathepsins as a functional link between apoptosis and autophagy. This hypothesis was confirmed by results of a recent study showing that inhibition of cathepsins by E64d, an inhibitor of papain-like cysteine proteases, resulted in a significant reduction of apoptotic cell numbers accompanied by an increase in autophagosome formation in MCF-7 cells exposed to camptothecin. ${ }^{58}$

\section{Conclusion}

The nature of triptolide to act as an anti-inflammatory, anticancer, and antiproliferative agent makes it an attractive alternative to current methods of cancer therapy. The untoward side effects of chemotherapy and radiation can be debilitating to the health of the patient and, in some cases, can actually make the cancer worse or bring on a new type of cancer. ${ }^{59,60}$ For these reasons, novel and safer alternative treatment modalities need to be investigated. A desirable and clean method of killing cancer cells is via programmed cell death. The dying cell dies in a self-contained fashion 
because the cellular contents remain membrane-bound and then the cell is removed by macrophages. It is often the goal of chemotherapeutic, radiation, and hormonal treatments to induce apoptosis in cancer cells. ${ }^{61,62}$

In the present study, we demonstrate that triptolide modulates apoptosis in MCF-7 cells by inducing lysosomal membrane permeability, increasing the expression levels of pro-apoptotic proteins, and inhibiting cell growth in a doseand time-dependent manner. To our knowledge, this is the first report in the literature of triptolide-induced lysosomal membrane permeability as an anticancer treatment. The importance of lysosomal-mediated programmed cell death has been underappreciated, and this study is innovative in the sense that it revisits this historically important organelle. Further studies are warranted to decipher the molecular mechanisms by which triptolide modulates programmed cell death in various cancer cells.

\section{Acknowledgment}

This work was supported by the National Institute of General Medical Sciences grant T34 GM079079 to RH. The authors also wish to thank Juan C Sanchez for technical assistance.

\section{Disclosure}

The authors report no conflicts of interest in this work.

\section{References}

1. National Cancer Institute's Website. Available from: http://seer.cancer. gov/statfacts/html/breast.html\#incidence-mortality.

2. Parkin DM, Bray F, Ferlay J, Pisani P. Global cancer statistics, 2002. CA Cancer J Clin. 2005;55:74-108.

3. Siegel R, Naishadham D, Jemal A. Cancer statistics, 2012. CA Cancer J Clin. 2012;62(1):10-29.

4. Li FQ, Lu XZ, Liang XB, et al. Triptolide, a Chinese herbal extract, protects dopaminergic neurons from inflammation-mediated damage through inhibition of microglial activation. J Neuroimmunol. 2004;148:24-31.

5. Qiu D, Kao PN. Immunosuppressive and anti-inflammatory mechanisms of triptolide, the principal active diterpenoid from the Chinese medicinal herb Tripterygium wilfordii Hook. f. Drugs R D. 2003;4:1-18.

6. Brinker AM, Ma J, Lipsky PE, Raskin I. Medicinal chemistry and pharmacology of genus Tripterygium. Phytochemistry. 2007;68: 732-766.

7. Chan MA, Kohlmeier JE, Branden M, Jung M, Benedict SH. Triptolide is more effective in preventing $\mathrm{T}$ cell proliferation and interferon-gamma production than is FK506. Phytother Res. 1999;13: 464-467.

8. Titov DV, Gilman B, He QL, et al. XPB, a subunit of TFIIH, is a target of the natural product triptolide. Nat Chem Biol. 2011;7:182-188.

9. Choi YJ, Kim TG, Kim YH, et al. Immunosuppressant PG490 (triptolide) induces apoptosis through the activation of caspase- 3 and down-regulation of XIAP in U937 cells. Biochem Pharmacol. 2003;66:273-280.

10. Lee KY, Chang WT, Qiu D, Kao PN, Rosen GD. PG490 (triptolide) cooperates with tumor necrosis factor- $\alpha$ to induce apoptosis in tumor cells. J Biol Chem. 1999;274:13451-13455.
11. Carter BZ, Mak DH, Schober WD, et al. Triptolide sensitizes AML cells to TRAIL-induced apoptosis via decrease of XIAP and p53-mediated increase of DR5. Blood. 2008;111:3742-3750.

12. Krosch TC, Sangwan V, Banerjee S, et al. Triptolide-mediated cell death in neuroblastoma occurs by both apoptosis and autophagy pathways and results in inhibition of nuclear factor-kappa B activity. Am J Surg. 2013;205:387-396.

13. Jain MV, Paczulla AM, Klonisch T, et al. Interconnections between apoptotic, autophagic and necrotic pathways: implications for cancer therapy development. J Cell Mol Med. 2013;17:12-29.

14. Maghsoudi N, Zakeri Z, Lockshin RA. Programmed cell death and apoptosis - where it came from and where it is going: from Elie Metchnikoff to the control of caspases. Exp Oncol. 2012;34:146-152.

15. Schweichel JU, Merker HJ. The morphology of various types of cell death in prenatal tissues. Teratology. 1973;7:253-266.

16. Zakeri ZF, Quaglino D, Latham T, Lockshin RA. Delayed internucleosomal DNA fragmentation in programmed cell death. FASEB J. 1993;7:470-478.

17. Kitanaka C, Kato K, Ijiri R, et al. Increased Ras expression and caspase-independent neuroblastoma cell death: possible mechanism of spontaneous neuroblastoma regression. J Natl Cancer Inst. 2002;94: 358-368.

18. de Liz R, Horst H, Pizzolatti MG, Fröde TS, Girard D. Activation of human neutrophils by the anti-inflammatory mediator Esenbeckia leiocarpa leads to atypical apoptosis. Mediators Inflamm. 2012; 2012:198382.

19. Halaby R, Zakeri Z, Lockshin RA. Metabolic events during programmed cell death in insect labial glands. Biochem Cell Biol. 1994;72:597-601.

20. de Duve C. The lysosome turns fifty. Nat Cell Biol. 2005;7:847-849.

21. Luzio LP, Pryor PR, Bright NA. Lysosomes: fusion and function. Nat Rev Mol Cell Biol. 2007;8:622-632.

22. Linder S, Shoshan MC. Lysosomes and endoplasmic reticulum: Targets for improved, selective anticancer therapy. Drug Resist Updat. 2005;8:199-204.

23. Johansson A, Appelqvist H, Nilsson C, Kagedal K, Roberg K, Ollinger K. Regulation of apoptosis-associated lysosomal membrane permeabilization. Apoptosis. 2010;15:527-540.

24. Česen MH, Pegan K, Spes A, Turk B. Lysosomal pathway to cell death and their therapeutic applications. Exp Cell Res. 2012;318: $1245-1251$.

25. Cheriyath V, Kuhns MA, Kalaycio ME, Borden EC. Potentiation of apoptosis by histone deacetylase inhibitors and doxorubicin combination: cytoplasmic cathepsin B as a mediator of apoptosis in multiple myeloma. Br J Cancer. 2011;104:957-967.

26. Kirkegaard T, Roth AG, Petersen NH, et al. Hsp70 stabilizes lysosomes and reverts Niemann-Pick disease-associated lysosomal pathology. Nature. 2010;463:549-553.

27. Shree T, Olson OC, Elie BT, et al. Macrophages and cathepsin proteases blunt chemotherapeutic response in breast cancer. Genes Dev. 2011;25:2465-2479.

28. Paquet C, Sané AT, Beauchemin M, Bertrand R. Caspase- and mitochondrial dysfunction-dependent mechanisms of lysosomal leakage and cathepsin B activation in DNA damage-induced apoptosis. Leukemia. 2005;19:784-791.

29. Mosmann T. Rapid colorimetric assay for cellular growth and survival: application to proliferation and cytotoxicity assays. J Immunol Methods.1983;65:55-63.

30. Tan BJ, Tan BH, Chiu GN. Effect of triptolide on focal adhesion kinase and survival in MCF-7 breast cancer cells. Oncol Rep. 2011;26:1315-1321.

31. Jänicke RU, Sprengart ML, Wati MR, Porter AG. Caspase-3 is required for DNA fragmentation and morphological changes associated with apoptosis. J Biol Chem. 1998;273:9357-9360.

32. Taimen P, Kallajoki M. NuMA and nuclear lamins behave differently in Fas-mediated apoptosis. J Cell Sci. 2003;116:571-583. 
33. Liu J, Jiang Z, Xiao J, et al. Effects of triptolide from Tripterygium wilfordii on ERalpha and p53 expression in two human breast cancer cell lines. Phytomedicine. 2009;16:1006-1013.

34. Soundararajan R, Sayat R, Robertson GS, Marignari PA. Triptolide: an inhibitor of a disintegrin and metalloproteinase 10 (ADAM10) in cancer cells. Cancer Biol Ther. 2009;8:2054-2062.

35. Leuenroth SJ, Okuhara D, Shotwell JD, et al. Triptolide is a traditional Chinese medicine-derived inhibitor of polycystic kidney disease. Proc Natl Acad Sci U S A. 2007;104:4389-4394.

36. Corson TW, Cavga H, Aberle N, Crews CM. Triptolide directly inhibits dCTP pyrophosphatase. Chembiochem. 2011;12:1767-1773.

37. Semenov DV, Aronov PA, Kuligina EV, Potapenko MO, Richter VA. Oligonucleosome DNA fragmentation of caspase 3 deficient MCF-7 cells in palmitate-induced apoptosis. Nucleosides Nucleotides Nucleic Acids. 2004;23:831-836.

38. Mizushima N. Transgenic models of autophagy. In: Deretic V, editor. Autophagy in Immunity and Infection: A Novel Immune Effector. Weinheim:Wiley-VCH; 2006;55-65.

39. Messina ME Jr, Halaby R. Does triptolide induce lysosomal-mediated apoptosis in human breast cancer cells? Med Hypotheses. 2011;77: 91-93.

40. Bratton SB, Salvesen GS. Regulation of the Apaf-1-caspase-9 apoptosome. J Cell Sci. 2010;123:3209-3214.

41. Germain M, Affar EB, D'Amours D, Dixit VM, Salvesen GS, Poirier GG. Cleavage of automodified poly(ADP-ribose) polymerase during apoptosis. Evidence for involvement of caspase-7. J Biol Chem. 1999;274:28379-28384.

42. Boucher D, Blais V, Denault JB. Caspase-7 uses an exosite to promote poly(ADP ribose) polymerase 1 proteolysis. Proc Natl Acad Sci USA. 2012;109:5669-5674.

43. Lockshin RA. Programmed cell death. Activation of lysis by a mechanism involving the synthesis of protein. J Insect Physiol. 1969;15: 1505-1516.

44. Schweichel JU, Merker HJ. The morphology of various types of cell death in prenatal tissues. Teratology. 1973;7:253-266.

45. Juhász G, Csikós G, Sinka R, Erdélyi M, Sass M. The Drosophila homolog of Aut1 is essential for autophagy and development. FEBS Lett. 2003;543:154-158.

46. Lockshin RA, Zakeri Z. Apoptosis, autophagy, and more. Int J Biochem Cell Biol. 2004;36:2405-2419.

47. Jochová J, Zakeri Z, Lockshin RA. Rearrangement of the tubulin and actin cytoskeleton during programmed cell death in Drosophila salivary glands. Cell Death Differ. 1997;4:140-149.

48. Halaby R, Martinez ML, Lockshin R, Zakeri, Z. 20-Hydroxyecdysone induces apoptosis in the labial glands of Manduca sexta. J Res Lepid. 2003;37:3-10.
49. Poole AR. Tumour lysosomal enzymes and invasive growth. In: Dingle JT, editor. Lysosomes in Biology and Pathology. Vol 3. Amsterdam: North-Holland Publishing Company; 1973;303-337.

50. Yu H, Lou JR, Ding WQ. Clioquinol independently targets NF-kappaB and lysosome pathways in human cancer cells. Anticancer Res. 2010;30:2087-2092.

51. Ivanova S, Repnik U, Bojic L, Petelin A, Turk V, Turk B. Lysosomes in apoptosis. Methods Enzymol. 2008;442:183-199.

52. Boya P, Andreau K, Poncet D, et al. Lysosomal membrane permeabilization induces cell death in a mitochondrion-dependent fashion. $J$ Exp Med. 2003;197:1323-1334.

53. Cirman T, Oresić K, Mazovec GD, et al. Selective disruption of lysosomes in HeLa cells triggers apoptosis mediated by cleavage of Bid by multiple papain-like lysosomal cathepsins. J Biol Chem. 2004;279:3578-3587.

54. Kim J, Klionsky DJ. Autophagy, cytoplasm-to-vacuole targeting pathway, and pexophagy in yeast and mammalian cells. Annu Rev Biochem. 2000;69:303-342.

55. Zhao M, Antunes F, Eaton JW, Brunk UT. Lysosomal enzymes promote mitochondrial oxidant production, cytochrome $c$ release and apoptosis. Eur J Biochem. 2003;270:3778-3786.

56. Brunk UT, Neuzil J, Eaton JW. Lysosomal involvement in apoptosis. Redox Rep. 2001;6:91-97.

57. Leist M, Jäättelä M. Triggering of apoptosis by cathepsins. Cell Death Differ. 2001;8:324-326.

58. Lamparska-Przybysz M, Gajkowska B, Motyl T. Cathepsins and BID are involved in the molecular switch between apoptosis and autophagy in breast cancer MCF-7 cells exposed to camptothecin. J Physiol Pharmacol. 2005;56:159-179.

59. Redding, SW, Haveman, CW. Treating the discomfort of oral ulceration resulting from cancer chemotherapy. Compend Contin Educ Dent. 1999;20:389-392,394,396.

60. Lorig KR, Sobel DS, Ritter PL, Laurent D, Hobbs M. Effect of a self management program on patients with chronic disease. Eff Clin Pract. 2001;4:256-262.

61. Xue LY, Chiu SM, Oleinick NL. Staurosporine-induced death of MCF-7 human breast cancer cells: a distinction between caspase-3dependent steps of apoptosis and the critical lethal lesions Exp Cell Res. 2003;283:135-145

62. Brown JM, Wouters BG. Apoptosis, p53, and tumor cell sensitivity to anticancer agents. Cancer Res. 1999;59:1391-1399.
International Journal of Women's Health

\section{Publish your work in this journal}

The International Journal of Women's Health is an international, peerreviewed open-access journal publishing original research, reports, editorials, reviews and commentaries on all aspects of women's healthcare including gynecology, obstetrics, and breast cancer. The manuscript management system is completely online and includes

\section{Dovepress}

a very quick and fair peer-review system, which is all easy to use. Visit http://www.dovepress.com/testimonials.php to read real quotes from published authors. 